International Journal of Social Science and Economic Research

ISSN: 2455-8834

Volume: 05, Issue: 06 "June 2020"

\title{
AN ASSESSMENT OF SUB-SAHARAN AFRICA DEBT PERFORMANCE AFTER THE DEBT RELIEF INITIATIVE
}

\author{
${ }^{1}$ Abubakar Sadiq Saleh, ${ }^{2}$ Abbas Umar Ibrahim \\ ${ }^{1}$ Dept. of Banking and Finance, University of Abuja, Nigeria \\ ${ }^{2}$ Dept. Business Administration, Nile University, Nigeria
}

DOI: 10.46609/IJSSER.2020.v05i06.006 URL: https://doi.org/10.46609/IJSSER.2020.v05i06.006

\begin{abstract}
By the turn of the new millennium, precisely during the late nineties, agitations for debt relief by rich nations and other creditor bodies to the low income ones climaxed in the creation of the Highly Indebted Poor Countries Initiative (HIPC). By the onset of the new millennium many poor countries had qualified for the initiative and benefitted from the relief. Debt relief can really free-up State funds for more developmental projects that can improve standard of living, help alleviate poverty and restore stability to the economy. It has however been argued that although the whole idea and process of debt relief was positively influenced by economic and institutional development, governments of creditor nations actually granted debt relief purely on political rather than economic considerations. The idea of path dependence was believed to be the reason behind the debt relief initiative (Freytag and Pehnelt, 2009). Others believe the whole idea behind debt relief is nothing more than an instrument of power at the disposal of rich creditor nations who control most of the international flow of capital corporations, and other international credit clubs such as the Paris club etc. Before qualifying for a debt relief debtor nations need to fulfil a series of conditions which turn out to be quite harmful to their economies and thereby endangering further their sovereignty and independence (Vallee and Vallee, 2005). The objective of this work is to carry out an assessment of the debt relief initiative among the countries in the sub-Saharan Africa. This assessment will be with a view to establishing the impact, if any, of the debt relief initiative on the economic performances of these countries. Data from the World Bank economic indicators; and the IMF world economic outlook would be utilised to form a causal relationship between debt relief and economic growth.
\end{abstract}

Keywords: Debt, Debt relief, performance assessment, economic growth, sub-Saharan Africa.

\section{INTRODUCTION}




\section{International Journal of Social Science and Economic Research}

ISSN: $2455-8834$

Volume: 05, Issue: 06 "June 2020"

Borrowing is a necessary aspect of governance. Sovereign debt is an unavoidable economic process for every nation. This is the reality for both rich and poor nations. Since capital resources like other economic resources are scarce in supply it follows that there is a cost for postponing the use of same to a later date. Thus, it makes economic sense for the investor to be adequately compensated by the borrower in accordance to agreed terms by the two parties. Sovereign debts are justified when the cost benefit analysis of the facility lead to an overall benefit for the economy in the form of capital formation, investment in infrastructure, and increased economic activities and growth. Since our needs are limitless borrowing to meet up deficits may equally be a necessary measure to carryout meaningful adjustments. Thus with a meaningful and effective plan to utilize borrowed funds efficiently sovereign debt could lead countries to economic prosperity and growth.

Over the years however experiences of countries, many of them low-income (e.g. in sub-Saharan Africa) and other developing countries (e.g. in Latin America) have shown that a larger proportion of the countries' economic crisis was directly or indirectly linked to external borrowing. For example, in the article, 'debt in the sub-Saharan Africa', Okosodo and Isedu (2008) confirmed and supported the existence of what is popularly referred to as the debt overhang hypothesis. In that study it was indicated that increases in resources outflow due to external debts servicing resulted in serious depression of domestic economic activities and how that could lead to a substantial contraction of the agricultural and manufacturing and other productive activities in a country. But external debts are no more harmful than domestic debts. External debts could be beneficial to an economy provided the borrowed funds are concessional, low interest and sourced for a longer term period. Domestic investments are however significantly hampered by excessive domestic debts, which may go along to wipe out substantial available funds for internal investments and by extension strangulate all means of internal economic activities.

A further specific view of the negative impact of debt on the sub-Saharan African economies was substantiated, where excessive sovereign debt (Adigbite, et al 2008) was seen as the major militating factor against the growth and development of the Nigerian economy. The debt servicing on huge borrowed funds was seen as a direct consequence of borrowed funds which excessively overburden the production capacity of the economy. It was argued that when debt is accumulated it has the tendency of reducing economic performance through overhang effect and other macroeconomic instability ranging from discouraged savings, worsening fiscal deficit, exchange rate depreciation, and balance of payment disequilibrium among others. Similarly, Despande (1997) explained using a sample of 13 countries that the claims of debt overhang effect is found to be valid and really exist. The assertion that external debt had a negative influence on the investment ratio of a country in debt was confirmed. Over the period under 


\section{International Journal of Social Science and Economic Research}

ISSN: $2455-8834$

Volume: 05, Issue: 06 "June 2020"

consideration, the investment ratio for the sampled countries displayed first, a rising tendency roughly up to the late seventies and then declined by the end of the eighties. Opposed to these postulations however, Cohen (1993) observed that although debt levels had insignificant overall effect, they seem to have a negative effect on growth particularly in the Latin American countries but not in African countries. Cordella, Ricci, and Ruiz-Arranz (2010) argued that excessive indebtedness by a nation could actually prove adverse for investments and its prospects, but pointed out that investments in highly indebted countries were not really affected by the debt burden. Instead, they explained that the real negative effect of debt on investment was actually significant among countries with lower indebtedness. Also looking at a sample of about 54 developing countries, Hansen (2001) could not find a conclusive evidence to support the assertion that external debt had any effect on economic growth. But Omotola and Saliu (2009) emphasized however that it is actually an economic fact to assert that Africa had been over burdened by debt. This is where debt crisis is seen as a situation in which indebted countries will be so much indebted to the extent that it becomes too difficult to sustain the management of the debt: a situation which most times resulted in severe economic distortions and internal instability.

The negative impact of debt on the prospects of domestic investments or what is regarded as debt overhang could be a condition that may not necessarily hold in all the processes of credit and whose probability is so uncertain and as such government borrowing could be beneficial to the borrowing nation. Thus, prudent management of borrowed resources should be the main preoccupation of debt-distressed countries. This is with a view to maintain their creditworthiness as well as keep their access to their sources of funds.

\section{DEBT RELIEF AS A REMEDY}

Given the adverse effects of external borrowing on low income countries particularly those in the sub-Saharan Africa, many debt-distressed African countries started to agitate for debt cancellation or debt relief. While the idea of debt relief gaining ground globally in the end of nineties, Cordella, Ricci, and Ruiz-Arranz (2010) doubted the effectiveness of the measure as an instrument of fostering growth among highly indebted countries. Since the beginning of the millennium however, groups around the world canvassed for debt relief or debt cancellation for several debt burdened nations in the sub-Saharan Africa. It was argued that with debt relief to debt ridden poor countries funds would be freed for investment in infrastructure and other developmental projects and reinvigorate economic activities to attain growth.

Debt relief was however viewed by many with suspicion, due to the array of conditions that usually accompany the measure. It was as such viewed as a different means of further entrapping the already debt-stricken poor nations' economies. For instance Vallee and Vallee (2005), 


\section{International Journal of Social Science and Economic Research}

ISSN: $2455-8834$

Volume: 05, Issue: 06 "June 2020"

argued that the whole idea behind debt relief was no more than an instrument of power at the disposal of rich creditor nations who control most of the international flow of capital through the multilateral financial institutions, multinational corporations, and other international credit clubs such as the Paris club and in some instances the NGOs. It was argued that before qualifying for a debt relief, debtor nations needed to fulfil series of conditions which turned out to be equally harmful to the economies of the beneficiary countries and thereby further endangering their sovereignty and independence. It was concluded that although the idea and process of debt relief was positively influenced by economic and institutional development, governments of creditor nations actually granted debt relief purely on political rather than economic considerations (Freytag and Pehnelt, 2009). It was further argued that debt relief if granted would ultimately lead to path dependence of the beneficiary countries.

Because it is not known whether the debt relief would be effective as a measure to free-up debt distressed countries' funds for investments in infrastructure, fresh studies theorising the benefits to the beneficiaries. It is however imperative for such debt-entrapped nations to first seek to embark on actual determination of their past commitments vis-a-vis the current, in prioritising strategies to make best use of the opportunity offered. Debt relief could actually set-free State funds for more developmental projects that can improve standard of living, help alleviate poverty and restore stability to the economy. Debt relief is however not similar to debt repudiation. In order to free resources for domestic economic development that were hitherto directed to debt servicing obligations some countries venture further into taking decisions to out rightly repudiate the debts. Tideman and Sharon (1991:255) argued that the process whereby countries seek to embark on refusal to honour debt obligations is bound to go a long way to effect an increase economic efficiency and social justice. Thus, this increase the debtors' credibility and also assures lenders that new loans made would be in the interest of the citizens of the debtor country.

But closely related to debt relief was the threat of deliberate measure of debt repudiation by poor debtor countries, which many saw to not really be a sound economic decision. It is argued that when nations refuse to attend to outstanding financial obligations, same indebted countries run the risk of losing their creditworthiness to enable them unhindered access to external sources of funding. This will obviously hinder prospects of economic growth. According to Montiel (2005: 261), debt repudiation could to some extent be a one way out for a country devastated by insolvency. However, there are instances when strong and solvent countries get tempted to decline their financial obligations. A country may just choose not to pay in order to avoid the excessive burden associated with the distortionary taxes if it were to settle its financial obligations. Although very attractive however, debt repudiation has its costs. The costs associated with debt repudiation (Montiel, 2005:261) could be both direct and indirect. The action is direct where a creditor not satisfied with the action of a debtor seeks for enforcement 


\section{International Journal of Social Science and Economic Research}

ISSN: $2455-8834$

Volume: 05, Issue: 06 "June 2020"

through the legal system and succeed in the process. If, however, unable to win an enforcement there are still some costs associated with default on the part of the debtor country. Eventually the creditors' ability to impose sanctions on a defaulting country could ruin credibility of the country leading to the real danger of a "debt overhang". This he argued could create certain level of problems for the domestic economic stability as well as other relative macroeconomic fundamentals. Consequently, the governments that repudiates will find it difficult to borrow in the future where at the end "the cost of repudiation is the loss of market access." This view is shared by Jeremy and Kenneth (1989:49), because when a smaller country embark on repudiation of its debt, it may only succeed in blocking access to its potential lenders arising from the outstanding legal rights of existing creditors. In any case however, those legal rights are usually only relevant for a country to access more credit. Furthermore, outright repudiation of debt by low-income countries could be costly when future flow of capital is considered. With this dilemma, the best option for an efficient and effective debt would be to seek for debt relief or outright debt cancellation.

Although rich in human and natural resources the African sub-continent lags behind other regions in terms of flow and availability of investible capital. Lacking sufficiency in the much needed capital resources, coupled with the problems of poverty, disease, poor infrastructure and the dwindling standard of living will continue unabated. In spite of this the sub-Saharan Africa was overburdened by the extent of its members' indebted-ness. Growing issues related to debt accumulation in sub-Saharan Africa resulted in considerable attention (Mbire and Atingi (1997) in both literature and in the view of leading serious global development of the period.

The United Nations (2000) reported that the external debt situation of developing countries was quite worrisome. The body noted that finding a resolution to the problems of the heavily indebted poor countries (HIPC), majority of who were in Africa was not quite easy. Though there were other poor countries that were also facing similar mounting debt burden as a result of worsening global economic conditions, a number of middle-income countries in East Asia had overcome the first phase of an acute balance-of payments crisis with their debt problems still unresolved. Comparatively some middle-income countries in Latin America were encountering serious payment problems. In summary as of the year 1999 total foreign debt outstanding against developing nations was $\$ 2.1$ trillion. A breakdown of this figure on a regional basis recorded $\$ 792$ billion for Latin America. A total of $\$ 340$ billion was owed by Africa, of which $\$ 175$ billion was actually outstanding against the sub-Saharan Africa. A total of $\$ 972$ billion was owed by Asia. It is noteworthy however that was while most of the Latin America's debt was owed to commercial banks, larger proportion Africa's debt was owed to official donors and multilateral organizations. More worrisome the conventional debt indicators, "such as the ratio of debt to GNP, sub - Saharan Africa's debt burden was 123\% of its GNP compared with $41.4 \%$ for Latin 


\section{International Journal of Social Science and Economic Research}

ISSN: $2455-8834$

Volume: 05, Issue: 06 "June 2020"

America and $28.2 \%$ for Asia. In terms of ratio of external debt to exports, the figures are striking: $340 \%$ for sub-Saharan Africa; 202\% for Latin America; and 121\% for Asia." (United Nations, 2000: 277)

But in its earlier report the IMF (1990), decided that external debt issues among borrowing nations could no longer be treated separately from other macroeconomic aggregates. Thus, debt was made a prominent factor in both the domestic fiscal environment and the management of balance of payments. It was evident that all decisions by countries to borrow was bound to affect certain macroeconomic activity or the other; and in turn also invariably affected by other forces.

Consequently, somewhere towards the late 1990s social and economic problems directly linked to the indebtedness of some developing countries led to incessant calls for debt relief or outright cancellation. The period following these mounting agitations, precisely in 1996, the Heavily Indebted Poor Country (HIPC) Initiative was set up by the international community, which was to serve as a debt relief program with its main focus to reduce to sustainable levels the external debt burdens outstanding against the eligible countries (ADB, 2010:3).

The matter of debt relief had, by the mid-2009 been made a policy, where many African countries having implemented the policy reforms as required by the IMF and the World Bank, qualified. Faloseyi (2007:7), noted that Nigeria qualified as a special HIPC case with 60 percent its debt owed Paris club cancelled, a move that witnessed the country's eventual escape from all of the Club's debt of a whopping \$US31billion. The country was then made to settle arrears to the tune of about \$US6 billion and then bought-back the remaining debt stock of about \$US7billion.

The quantum of concession under the debt relief initiative had by the end of 2008, reached a total estimated cost of US\$74.4 for all eligible HIPCs (33 of which are in sub-Saharan Africa). Of this amount the ADB was owed the sum of US\$5.3 billion only. However, the ADB recorded in its report that though debt relief initiative actually succeeded in reducing the affected countries' quantum of debt stock and in the process helping to free funds for effecting poverty-reducing expenditures; it was obvious that several low-income countries in Africa remained economically weak with fast-deteriorating debt conditions. This according to the apex regional body was due to the countries' tendency to re-accumulation of debt at a rate faster than can be sustained by the growth of their gross domestic product and exports or as a result of their inability to withstand external shocks. Ghana assessed at the beginning as a viable "post-completion point" performer had its debt distress risk ratio so early by the second half of 2008, served as a good instance of the vulnerability of the low income countries even after the much taunted debt relief (ADB, 2010: 3-5). 


\section{International Journal of Social Science and Economic Research}

ISSN: $2455-8834$

Volume: 05, Issue: 06 "June 2020"

It is imperative to prioritise the development of an African initiative to tackle the debt problem to ensure a long run stable African economy. This becomes pertinent because Africa being a continent vast in natural resources, and possessing all the prerequisite of a developed and advanced continent. But with debt relief granted many African nations, most of which were seen once again struggling in debts without a clear strategy for their management, the economic crisis in region seemed to have compounded. Furthermore, most facilities fail to perform and potentially end up bad because right from the onset their terms were not followed before being contracted. And after being awarded many of the facilities are used for purposes other than that they were actually intended for all due to bad planning and absence of an effective management strategy. This situation in the long run has serious negative repercussions with the repayment in the short run and on the economy in the long run. Absence of a sound debt management strategy at the micro level of a corporate entity and at the macro level when dealing with national economies always portrays danger for economic growth of a nation. Thus a sound and effective debt management strategy is needed for any meaningful economic growth plan strategy of a nation and its importance cannot be overemphasized. And hence the problem with borrowing is not the proverbial source but most of the time its destination. The World Bank (1990) explained that debt management strategy is strictly in the borrower country's best interests. According to the Bretton Wood institution a sound debt management is regarded as a priority, a sensible and flexible way to assist the authorities in policy formulations that are aimed at reducing cost of borrowing, refinancing, or trimming down the nation's level of indebtedness.

However, in certain sub - Saharan countries such as Nigeria, immediately after the debt relief (actually debt cancellation) was granted by the International Financial institutions of the World Bank and the IMF as well as the Paris and London clubs, a Debt Management Offices were set up independent of the Central Banks.

The effect of debt and the threat of overhang on the economy, and all other negative tendencies, the option of nations resorting to debt repudiation as a strategy could prove perilous. Debt repudiation by a sovereign nation was presumed an illegality, and never regarded as a worthy economic option. For example there is bound to be a problem of loss of a country's international creditworthiness, which invariably affects its chances of sourcing further funds for more investment in the entire needed infrastructure for development. And since there is no precise proof for a case of debt over-hang (Nurazira, Daud and Podivinsky, 2011) it was considered more expedient for debt distressed nations in the SSA to embark on a correction of misallocation of borrowed funds with a view to putting in place a sound, effective and transparent debt management policy. And most importantly to pursue an aggressive strategy to engage the creditor nations and institutions to seek for debt relief or total cancellation of all outstanding facilities, to enable them focus on infrastructural development. 


\section{International Journal of Social Science and Economic Research}

ISSN: $2455-8834$

Volume: 05, Issue: 06 "June 2020"

The economic turmoil currently caused by the Covid-19 pandemic globally further exposes the sub-Saharan Africa to threats of further economic crisis that could engulf the region. While most of these countries are overburdened with debt and debt servicing; agitation for debt relief has never been timelier. The IMF has since considered granting debt relief to a select countries to enable them tackle the menace of the covid-19 pandemic and its economic consequences. Studies such as the one presented would prove most valuable in understanding the effect of debt relief on the ability of lower income countries to provide infrastructure in the form of improved access to electricity, transportation, and now healthcare.

\section{METHODOLOGY}

This study adopts the quantitative approach where we build causality between the quantum of debt relief granted to a sub-Saharan country on one hand as the dependent variable, and the variables of access to electricity as a percent of GDP (AE), Air transport registered carriers worldwide (ATRCDW), and Railways; passengers carried, millions per kilometre (RPCKM) being the independent variables on the other. We consider the multiple correlation-ship to ascertain how debt relied or forgiveness to a debt distressed and straddled nation would have freed resources for investment in infrastructural development in both the medium and longer term periods.

Access to electricity is a vital indicator of economic development and possibility of economic growth. Electricity is the bedrock of manufacturing without which investment in and other processes of production would certainly be significantly affected negatively if not completely grounded. Even where alternative fuels are employed as substitute electricity remains the leading factor in industrialisation. The chances of increased and sustained production growth are doubtful without steady electricity. Access to Electricity is necessary for growth but unfortunately very low for countries in the sub-Saharan Africa. These low income countries need to embark on aggressive provision of increasing their people's access to electricity for the purpose of improved investment, manufacturing, production and eventual economic growth. According to Kanagawa, M., and Nakata, T. (2008) access to electricity consumption was found to have a significant correlation with GDP and HDI of about 120 surveyed countries. It was discovered that countries that make high consumption level of per capita electricity consumption, tend to attain higher GDP per capita and the human development index (HDI). The mass electrification of communities in a country is however known to be a capital intensive venture consuming huge amount of funds. Thus, for the SSAs to be able to attain sufficient level of electrification they require huge capital investments which may invariably be lacking once such a country is saddled with huge amounts in debt servicing. For a low-income, poor sub-Saharan African nation, which is entangled in debt crisis, the ability to concentrate funds in infrastructural 
International Journal of Social Science and Economic Research

ISSN: $2455-8834$

Volume: 05, Issue: 06 "June 2020"

development is far more beneficial than excessive debt servicing that could lead to further decline in investible funds. This is evident since, accessibility to energy tend to influence the socio-economic conditions of developing countries. Likewise, access to modern energy such as electricity is bound to improve the quality of life of the people.

An important factor propelling the growth of an economy is the connectivity of economic activities between regions, communities, and settlements through an effective and viable modes of transportation in a country. Good transportation system make possible the mobility of ideas, goods, and services that help in the generation of employment, income level, increased investments, productivity, and boost in exports and the balance of payment situation.

Lesser developed economies such as those in the sub-Saharan Africa have poor transportation systems and as a result the study include the air transport registered carriers worldwide (ATRCWD), and the Railways passengers carried, millions per kilometre (RPCKM) indices as two important variables for study; to represent the extent of the infrastructural development in the SSAs. The three variables including the earlier discussed variable of access to electricity (AE) served as independent variables in a causality relationship with the dependent variable of debt relief.

\section{HYPOTHESIS:}

$\mathrm{H}_{0}$ : Debt relief has a positive impact on infrastructural development

$\mathrm{H}_{0}$ : Debt relief has a positive effect on economic growth of the recipient country

\section{PRESENTATION OF RESULTS}

In this section, the results are presented and major findings are discussed. The section begins with descriptive statistics of study variables covering the period of eleven years from 1980 to 2017, correlation matrix and regression analysis (fixed-effect GLS and OLS). In this section also the individual country result are discussed.

Table 4.1: Descriptive Statistics of the known variable

\begin{tabular}{llllllll|}
\hline Variable & Obs & Mean & Std Dev & Min & Max & Skewness & Kurtosis \\
\hline DFRUS & 152 & 3.2512 & 3.7714 & 0 & 10.0369 & 0.0532 & - \\
AE & 152 & 1.3766 & 0.3774 & 0.3487 & 1.9933 & 0.0011 & 0.2386 \\
ATRCDW & 152 & 3.8959 & 0.6274 & 2.4199 & 4.9923 & 0.0106 & 0.9809 \\
RPCKM & 152 & 2.1942 & 0.7111 & 0.7014 & 3.4343 & 0.0000 & 0.3507
\end{tabular}

Source: Generated by the researcher, using Stata (Version 13) 


\section{International Journal of Social Science and Economic Research}

ISSN: $2455-8834$

Volume: 05, Issue: 06 "June 2020"

Table 4.1 presents the descriptive statistics of all the variables used in this study and it shows the mean, standard deviation, minimum and maximum values of sampled countries. All variables employed in this study are closely spread out as can be seen from the close margins between their means and standard deviations' figures. Likewise, in their minimum and maximum figures. Also positive mean values of the dependent variable indicate an upward change in its value. The analysis of the table conveys that, the Debt forgiveness or reduction has an average of $\$ 3.2 \mathrm{~m}$, Access to electricity, $\$ 3.9 \mathrm{~m}$, Air transport, registered carrier departures worldwide and $\$ 2.2 \mathrm{~m}$ Railways facilities.

Table 4.2: Correlation Matrix

\begin{tabular}{llllll|}
\hline Variables & DFRUS & AE & ATRCDW & RPCKM & VIF \\
\hline DFRUS & 1.0000 & & & & 1.96 \\
AE & -0.2266 & 1.0000 & & & 1.55 \\
ATRCDW & -0.2053 & 0.4272 & 1.0000 & & 1.42 \\
RPCKM & -0.1830 & 0.1986 & 0.4229 & 1.0000 &
\end{tabular}

Source: Generated by the researcher, using Stata (Version 13)

Table 4.2 shows the results of the spearman rank correlation between the dependent variable Debt forgiveness or reduction (current US\$) and explanatory variables of Access to electricity as $\%$ of population, Air transport, registered carrier departures worldwide, and Railways, passengers carried (million passenger-km).The relationship between DFR and DFR is perfect. $\mathrm{AE}$ has a weak and positive relationship with the dependent variable DFR. There is weak and negative relationship between ATRCDW and DFR. Also, RPCKM shows a weak and negative association with DFR of the sampled countries. However, ATRCDW and RPCKM have weak and positive association with AE while RPCKM weak and positive relationship with ATRCDW.

The study also indicates no presence of multicollinearity in the independent variables with a Variance Inflation Factor (VIF) mean of 1.64 which is less than 10 as the bench mark, this result provides evidence of the absence of collinearity (see table 4.2). This shows that the explanatory variables in this are not interrelated. A heteroscedasticity test conducted to ascertain the variability of error term being constant or not indicated a presence of heteroscedasticity in the data set implying that the error term is not constant with a significant p-value of 0.0636 . To correct the situation of heteroscedasticity the robust standard error test was conduct (see table 4.3).

Furthermore the study conducted a hausman specification test to choose between fixed effect and random effect regression. This test is meant to check the trade-off between the efficiency of random effect and the consistency of fixed effect. The study revealed that fixed-effects model is 


\section{International Journal of Social Science and Economic Research}

ISSN: $2455-8834$

Volume: 05, Issue: 06 "June 2020"

more efficient than the random-effect with the p-value of 0.0560 and hence, the random-effect are rejected in favour of the fixed-effect model. This was chosen after preliminary tests of its assumptions. Thus, a robustness test is carried out in order to ensure the validity of all statistical inferences for this study and to check for any outliers among the regression standardized residuals.

Table 4.3: Panel Regression Result OLS and GLS (Fixed Effect)

\begin{tabular}{|c|c|c|c|c|c|c|}
\hline & \multicolumn{3}{|c|}{ OLS Result } & \multicolumn{3}{|c|}{ GLS Result (Fixed Effect) } \\
\hline Variables & Coef & $\mathrm{T}$ & $\mathrm{t}>/ \mathrm{t} /$ & Coef & $\mathrm{t}$ & $\mathrm{t}>/ \mathrm{t} /$ \\
\hline CONSTANT & 8.838 & 4.70 & 0.000 & 29.731 & 7.62 & 0.000 \\
\hline $\mathrm{AE}$ & -1.333 & -4.43 & 0.156 & -6.111 & -3.72 & 0.000 \\
\hline ATRCDW & -0.548 & -0.83 & 0.407 & -2.772 & -5.11 & 0.000 \\
\hline RPCKM & 0.735 & -1.42 & 0.159 & -3.313 & -7.62 & 0.000 \\
\hline R2 & 0.086 & & & R-sq: Within & & \\
\hline Adj. R2 & 0.067 & & & Between & & \\
\hline Vif & 1.64 & & & 0verall & & \\
\hline Hettest & 0.83 & & & Prob. > F & & \\
\hline Prob.> F & 0.004 & & & & & \\
\hline
\end{tabular}

Source: Generated by the researcher, using Stata (Version 13)

Table 4.3 shows the OLS and GLS (Fixed Effect) result. The p-value of the both OLS and GLS model of 0.004 and 0.000 show that the relationship between independent and dependent variables of the sampled countries is statistically significant. R-square shows 0.047 indicating that of $4.7 \%$ of the total variation in Debt forgiveness or reduction could be explained by the explanatory variables i.e. the variables of Access to electricity (\% of population), Air transport, registered carrier departures worldwide and Railways, passengers carried (million passenger$\mathrm{km}$ ). The remaining $95.3 \%$ of the total variation in the Debt forgiveness or reduction (current US\$) and explanatory variables are caused by factors not captured in the model.

The aggregate result indicates that explanatory relationship between the listed variables and the dependent variable of debt forgiveness scarcely exist.

GLS result of the regression analysis of the dependent variable DRF and the independent variable $(A E, A T R C D W$ and $R P C K M) . R^{2}$ within $=0.25$, between $=074$ and overall $=0.08$ show the relationship between the variables under consideration. The $\mathrm{R}^{2}$ of $74 \%$ means that the relationship between DFR and AE, ATRCDW, RPCKM has a positively strong relationship. $\mathrm{R}^{2}$ $=0.08$ shows that about $8 \%$ of the total variation in DFR could be explained by the explanatory variables AE, ATRCDW, RPCKM with Prob.> F equal 0.000 clearly indicates that the four variables under consideration has a significant difference in their mean at $1 \%$ significance level. The remaining $92 \%$ of the total variation in the DFR and AE, ATRCDW, RPCKM are caused by 


\section{International Journal of Social Science and Economic Research}

ISSN: $2455-8834$

Volume: 05, Issue: 06 "June 2020"

factors not captured in the model. There is significance negative effect of Access to electricity on debt forgiveness or reduction at $1 \%$. This result also revealed an inverse relationship between air transport, registered carrier departures worldwide and debt forgiveness or reduction at $1 \%$ level of significance. Also, Railways, passengers carried has significant negative effect on debt forgiveness or reduction at $1 \%$.

\section{RESULT DISCUSSION}

The result of Fixed-Effect shows that there is a significant negative effect of Access to electricity on debt forgiveness or reduction at $1 \%$. This result suggest that a reduction in debt or forgiveness of debt can increase Access to electricity of the sampled countries. Also, negative effect of air transport, registered carrier departures worldwide on Debt forgiveness or reduction at $1 \%$ suggest that as debt continued to be reduced or forgiven there will be increases in the provision of air transport, registered carrier departures worldwide by sampled countries. However, railway passengers carried variable has a significant negative effect on debt forgiveness or reduction at $1 \%$.

Access to electricity, air transport, registered carrier departures worldwide and railways, passengers carried shows negative relationship with debt forgiveness or reduction. This indicates that a decrease in debt or forgiveness of debt could cause about $1 \%$ increase in access to electricity of population, air transport, registered carrier departures worldwide and railways, passengers carried of the sample countries. This result is in line with the postulation that debt relief or forgiveness could free funds from excessive debt servicing to the provision of infrastructure. This confirms the hypothesis that debt forgiveness or reduction have an inverse relationship with air transport, registered carrier departures worldwide, railways, passengers carried and access to electricity of population of countries in the world especially, the emerging countries such as Uganda, Ghana, Kenya and Nigeria sampled in this study. In addition, the findings contradicts the findings by Freytag and Pehnelt, (2009) who asserted that the debt relief was purely granted on political rather than economic considerations. And who found significant relationship between the constructs whatsoever. Therefore, the study fails to reject the null hypothesis that postulates that there is a significant effect of debt relief or forgiveness on the infrastructural development of the sampled countries. This result implies that an attempt to forgive or reduce debt of the sampled countries can go a long way in improving basic amenities such as access to electricity of Uganda, Ghana, Kenya and Nigeria. Thus, upward changes in the provision of infrastructural facilities would be anticipated when a countries debt is forgiven or reduced. 
International Journal of Social Science and Economic Research

ISSN: 2455-8834

Volume: 05, Issue: 06 "June 2020"

Table 4.3: OLS Regression Result of individual country

\begin{tabular}{|c|c|c|c|c|c|c|c|c|c|c|c|c|}
\hline Vairables & \multicolumn{3}{|l|}{ Uganda } & \multicolumn{3}{|l|}{ Ghana } & \multicolumn{3}{|l|}{ Kenya } & \multicolumn{3}{|l|}{ Nigeria } \\
\hline & Coef & $\mathrm{t}$ & $t>/ t /$ & coef & $\mathrm{T}$ & $t>/ t /$ & Coef & $\mathrm{t}$ & $t>/ t /$ & Coef & $\mathrm{T}$ & $t>/ t /$ \\
\hline Constant & 22.661 & 4.94 & 0.000 & 45.777 & 2.30 & 0.028 & 22.877 & 0.38 & 0.708 & 69.990 & 4.94 & 0.000 \\
\hline $\mathrm{AE}$ & -9.687 & -2.99 & 0.029 & -9.295 & -1.34 & 0.189 & -5.257 & -2.86 & 0.007 & -21.404 & -3.06 & 0.004 \\
\hline ATRCDW & -1.377 & -1.00 & 0.324 & -3.649 & -1.78 & 0.085 & 0.653 & 0.23 & 0.819 & -4.346 & -2.60 & 0.014 \\
\hline RPCKM & -4.336 & -3.03 & 0.005 & -6.436 & -1.53 & 0.134 & -0.347 & -0.07 & 0.943 & -5.072 & -3.31 & 0.002 \\
\hline R2 & 0.38 & & & 0.16 & & & 0.256 & & & 0.43 & & \\
\hline Adj R2 & 0.32 & & & 0.09 & & & 0.191 & & & 0.38 & & \\
\hline Hettest & 0.79 & & & 0.08 & & & 0.83 & & & 0.19 & & \\
\hline Vif & 3.36 & & & 3.83 & & & 3.13 & & & 1.58 & & \\
\hline Prob $>$ F & 0.001 & & & 0.105 & & & 0.017 & & & 0.003 & & \\
\hline
\end{tabular}

Source: Generated by the researcher, using Stata (Version 13)

\section{Uganda}

For Uganda, the OLS result shows that the p-value of OLS model of 0.001 show that the relationship between independent and dependent variables of the sampled country is statistically significant. R-square shows 0.38 . This means that of $38 \%$ of the total variation in Debt forgiveness or reduction could be explained by the explanatory variables Access to electricity (\% of population), Air transport, registered carrier departures worldwide and Railways, passengers carried (million passenger-km). The remaining $62.3 \%$ of the total variation in the debt forgiveness or reduction (current US\$) and explanatory variables are caused by factors not captured in the model.

Access to electricity and air transport, registered carrier departures worldwide shows an inverse relationship with debt forgiveness or reduction. This indicates that decrease in debt or reduction in debt cause about $2.9 \%$ and $0.5 \%$ decrease in access to electricity and air transport, registered carrier departures worldwide of the sample countries respectively. This result is in line with the postulation that debt forgiveness or reduction affect access to electricity and air transport, registered carrier departures worldwide of countries in the world. In line with these findings are the results where a positive significant relationship between access to electricity and air transport, registered carrier departures worldwide and debt forgiveness or reduction. Therefore, the study fails to reject the null hypothesis that there is a significant effect of the aspect of debt forgiveness and the infrastructural development of the sampled countries.

This result implies that an attempt to grant debt relief or forgive or reduce debt figure of a country as represented by the sampled countries can cause an improvement in the area of access to electricity and air transport of Uganda. Thus, upward changes in the provision of infrastructural facility would be anticipated when a countries debt is forgiven or reduced. 


\section{International Journal of Social Science and Economic Research}

ISSN: $2455-8834$

Volume: 05, Issue: 06 "June 2020"

\section{Nigeria}

For Nigeria, the OLS result shows that the p-value of OLS model of 0.003 show that the relationship between independent and dependent variables of the sampled country is statistically significant. R-square shows 0.43 . This means that of $43 \%$ of the total variation in Debt forgiveness or reduction could be explained by the explanatory variables, of Access to electricity (AE), Air transport, registered carrier departures worldwide (ATRCDW) and Railways, passengers carried (RPCKM). The remaining $57 \%$ of the total variation in the Debt forgiveness or reduction and explanatory variables are caused by factors not captured in the model.

The result of OLS shows that there is significance negative effect of Access to electricity on debt forgiveness or reduction at $1 \%$. This result suggests that a reduction in debt or forgiveness of debt can increase access to electricity of the sampled countries. Also, negative effect of air transport, registered carrier departures worldwide on debt forgiveness or reduction at $1 \%$ suggest that as debt continued to be reduced or forgiven there will be increases in the provision of air transport, registered carrier departures worldwide by sampled countries. However, railways, passengers carried have significant negative effect on debt forgiveness or reduction at $1 \%$.

Access to electricity, air transport, registered carrier departures worldwide and railways, passengers carried shows negative relationship with debt forgiveness or reduction. This indicates that a decrease in debt or forgiveness of debt could cause about $1 \%$ increase in access to electricity of population, air transport, registered carrier departures worldwide and railways, passengers carried of the sample countries. This result is in line with the null hypothesis that there is a significant relationship between debt relief and debt forgiveness with the ability for a country to provide infrastructure. It follows that there is an inverse relationship between debt reduction with air transport, registered carrier departures worldwide, railways, passengers carried and access to electricity of population of countries in the world; specifically in an emerging economy such as Nigeria, one of the sampled countries in this study. Also, the findings contradict the result of Vallee and Vallee (2005), argued that the whole idea behind debt relief was irrelevant and no more than a political strategy by creditors in the advanced economies to further control the weaker economies. Therefore, the study do not reject the null hypothesis that there is a significant effect of debt relief on the economies of the sampled countries. This result implies that an attempt to forgive or reduce debt of the sampled countries can go a long way in improving basic amenities such as access to electricity of Uganda, Ghana, Kenya and Nigeria. Thus, upward changes in the provision of infrastructural facilities would be anticipated when a country's debt is forgiven or reduced.

\section{Ghana and Kenya}


International Journal of Social Science and Economic Research

ISSN: $2455-8834$

Volume: 05, Issue: 06 "June 2020"

Furthermore, there is however an evidence of statistical insignificance of the model using the data on Ghana. It does not therefore contribute to the general model. However, Kenya's model is found to be significant but the independent variables of Access to electricity, Air transport, and registered carrier departures worldwide, and Railways, passengers carried did not explain the effect of Debt forgiveness or reduction.

\section{CONCLUSION}

With the exception of data on Ghana all the sampled countries' data on debt forgiveness have indicated sufficient causality between debt forgiveness and the provision of infrastructure in the area of electricity and its accessibility, Air transportation and registered carrier departures worldwide, and Railways, passenger carried. Although unexplained in the case of Kenya, about one half of the sampled countries' resulted in an inverse relationship between the dependent and independent variable. Thus, debt relief or debt forgiveness is bound to make a positive impact on the economies of the recipient countries, and should be encouraged.

\section{REFERENCES}

ADB, (2010), 'Balancing Debt and Development.' African Development Fund Series, PP 3-4

Adegbite, E.O, Ayadi, F.S and Ayadi, O.F. (2008), 'The Impact of Nigeria's external debt on economic development.’ Vol 2 No.1, PP 268

Cordella, T., Luca, A.R. and Ruiz-Arranz, M. (2010), 'Debt Overhang or Debt Irrelavance?' IMF Staff Papers. Vol. 57, No.1, pp 18

Cohen, D. (1993), 'Low Investment and Large LDC Debt in the 1980s.' American Economic Review, Vol, 83 No. 3, pp 437 -49

Desphande A. (1997), 'The Debt Overhang and Disincentive to Invest'. Journal of Development Economics, Vol 52, No1, pp $185-186$

Freytag, A., \& Pehnelt, G. (2009). Debt Relief and Governance Quality in Developing Countries. World Development, 37(1), 62-80. Doi: 10.1016/j.worlddev.2008.01.004

Hansen, H. (2001), 'the Impact of Aid and External Debt on Growth and Investment: Insight from Cross Country Regression Analysis.' WIDER Conference on Debt Relief, UN University, Helinski, Finland, Aug. 17.

IMF, (2009), 'Regional Economic Outlook: Sub-Saharan Africa, Weathering the Storm.' World Economic and Financial Surveys, www.imf.org 
Kanagawa, M., and Nakata, T. (2008)

Mbire and Atingi (1997), 'Growth and Debt: The Ugandan Experience.' African Economic Research Consortium. AERC Research Paper 66

Monteil, P.J. (2005), 'Public Debt Management and Macroeconomic Stability: An Overview.' The World Bank, 259 - 281

Nurazira S., Daud M. and Podivinsky J.M. (2011), 'Debt-Growth Nexus: A Spatial Econometrics Approach for Developing Countries.' World Transition Economy Research, Vol.18 No. $1-15$

Okosodo, L.A. and Isedu, M.O. (2011), 'The Impact of External Debt Burden On the Growth of Agricultural and Manufacturing Sectors in The Nigerian Economy (1980 - 2008).' Interdisciplinary Journal of Contemporary Research in Business. Vol3, No.2

Omotola, J.S. and Saliu, H. (2009), 'Foreign aid, debt relief and Africa's development: problems and prospects.' South African Journal of International Affairs. Vol.16, No.1

Tideman, N. and Lockwood, S. (1993), 'The Legitimate Repudiation of A Nation's Debts.' Eastern Economic Journal. Vol. 19, No.3, 18

United Nations (2000), ‘World Economic and Social Survey 2000 (New York: UN): pp 276 -277

Vallee, O. and Vallee, S. (2005), 'The Poverty of Economic Policy: Is Debt Sustainability Really Sustainable?' Journal of International Affairs. Vol.58, No.2

World Bank (1990), 'Debt Management Systems.' World Bank Papers. WDP-108 